\title{
sciendo
}

DOI 10.2478/sbe-2019-0046

SBE no. 14(3) 2019

\section{THE ROLE OF COHESION POLICY IN THE DEVELOPMENT OF ROMANIA}

\author{
LUCIAN PAUL \\ Lucian Blaga University of Sibiu, Romania
}

\begin{abstract}
:
Cohesion is a common European value. The E.U.'s cohesion policy is and will remain an essential financing instrument for various multiannual development programs, for both member states and regions. This policy contributes to the development of the European Union, by reducing disparities between regions, generating jobs and increasing GDP per capita. The current paper aims to highlight several accomplishments and failings of the current cohesion policy, with a particular focus on post-2007 Romania, as well as taking a look at the future policy, envisioned for 2021 2027. The cohesion fund is making investments in areas such as digital infrastructure, innovation, combating climate change, ecological transition, energy, health and others. The main criterion on which this kind of financing is made is GDP per capita; however, other criteria have been added as well: youth unemployment, level of education, climate change and likely, migrant integration, in the near future. The European Commission proposes that, for the next multiannual financial framework, namely 2021 - 2027, local authorities become more involved in managing E.U. funds, particularly cohesion funds. Several new elements have been identified, for this following time frame, which will contribute to the modernization of the cohesion policy; they include investments across all regions, making them more accessible to E.U. citizens, making it more adapted to regional development and linking it to the European semester.
\end{abstract}

Key words: economic social and territorial cohesion, Cohesion Fund, Cohesion Policy, European fund

\section{Introduction}

To achieve an overall, harmonious development, the E.U. continues on its path towards strengthening economic, social and territorial cohesion. The European Union aims to diminish disparities among its developed and underdeveloped regions. As such, member states must build their economic policies while ensuring European set objectives are met. Through these objectives, the E.U. actually supports the acceleration of economic, social and territorial cohesion. Thus, the cohesion policy is complementary to other policies within the European Union, addressing areas such as education, employment, energy, the environment, the single market, research and development. This 
European policy provides both the framework and strategy for investments required to meet expected growth targets established within the "Europe 2020" strategy.

By analysing the results of the current cohesion policy, the current paper aims to highlight the need for change within the next cohesion policy, both at an European level, as well as for Romania.

\section{Background}

Cohesion is a complex political concept which aims to ensure social peace, through investments focused on three areas, namely economic, social and territorial investments. Through the Treaty of Rome, signed in 1957, the European Community set forth its main objective, for the entirety of its territory: ensuring the harmonious, balanced and durable development of all its economic activities, a high degree of employment and social protection. The existing economic, social and territorial gaps were identified ever since the common market was established; they persist to this day, when considering new member states and poorly developed regions and areas, particularly due to industrial decline.

Article 235 of the Treaty of Rome emphasizes the continuous preoccupation of all member states to "strengthen the unity between their economies and to ensure a harmonious development, while reducing the gaps between regions". Also, the founding members acknowledged the need to diminish the impact of economic integration on the labor force, as well as the need to ensure a financial equilibrium between developed and underdeveloped regions.

At the same time, article 174 mentions that, in order to consolidate economic, social and territorial cohesion, the Union seeks to reduce gaps and disparities between the development levels of various regions. Special attention is provided to rural areas, areas affected by industrial transition, areas affected by natural factors, but also areas affected by severe and permanent demographic decline.

The cohesion policy finances elaborate, multiannual development programs, built through collaboration among regions, member states and the Commission. These programs are proposed by the Commission for the entirety of the European Union (Marin, Socol, Marinas, 2004).

The Cohesion Fund intervenes across an entire national territory, particularly for large projects concerning environment protection and trans European transportation networks; the reasoning behind these interventions is so that such projects do not perturb internal budgetary efforts, needed to satisfy the requirements of the economic and monetary union. Furthermore, the Fund helps member states to adhere to E.U. norms within these areas.

Analyses conducted at European level underline that disparities among regions and member states are linked to unequal social and economic development, but also to existing natural resources, high unemployment, inadequate infrastructure and a deficient educational and healthcare system. 
The European Union believes its cohesion policy can and should be regarded as an instrument for the advancement of integration, be it economic, social, cultural and political integration (Popescu, 2007).

The cohesion and regional policies are believed to be synonymous. In fact, the E.U.'s regional policy was established precisely to improve the Union's regional policy. The unitary monitoring of structural and cohesion policies by various member states who benefit from these funds made it necessary to create territorial statistics structures in all these countries. These structures are trusted with determining the eligible regions for receiving such assistance, via structural instruments (Lucian, 2016).

The E.U.'s regional policy is invariably linked to the horizontal size of the cohesion policy: first and foremost, it is a solidarity policy, built around its main objective, namely social and economic cohesion. Its main particularity resides in it being horizontal, meaning it is interconnected with all communitarian policies.

Also, the cohesion policy is linked to the E.U.'s sectorial policies, such as transportation, environment and education. These policies have clear priorities, established through the E.U. Treaty, but have few actual financial means, so as to reach their perspectives. In general, each member state must identify all available financial resources, so as to achieve these priorities. The cohesion policy extracts its priorities from the characteristics of sectorial policies, focusing on those priorities which contribute to reducing development disparities between states and regions. On the other hand, the cohesion policy supports the objectives of sectorial policies, through substantial communitarian financial support. Since cohesion is one of the E.U.'s priorities, the Union allocates one third of its budget towards it.

By knowing these challenges, which the cohesion policy generally faces, the E.U. can allocate non-refundable funds towards projects which reduce inequalities between regions, particularly those regions where GDP per capita is below $75 \%$ of the European average.

At European level, the multiple objectives of the cohesion policy are achieved by financing projects through the European Regional Development Fund (ERDF) and the Cohesion Fund (CF), but also through the degree of absorption of E.U. funds, by each member state. As such, the cohesion policy stimulates additional funding from public and private funds, across all member states. The objectives of the cohesion policy are financed through three main funds:

- The European Regional Development Fund (ERDF), which seeks to consolidate economic and social cohesion at a regional level, through investments in sectors which create jobs. In addition, the Fund also finances transborder cooperation programs;

- The European Social Fund (ESF), which invests in individuals, preparing them to occupy a job, supporting disabled individuals, as well as individuals who face poverty and social exclusion;

- The Cohesion Fund (CF), which invests in member states which have a GDP per capita of below $90 \%$ of the E.U. average. It supports ecological projects and projects in durable development. 
Aside from these funds, other funds are available as well, and are part of the cohesion policy: FEADR and FEPM, which together make up the European Structural Fund, as per the Council's Regulation, no. 1303 per 2013.

Between 2014 and 2020, the prerequisites for selection and management, for all these programs, have been improved, as focus was placed on measurable results and the simplification of common accessing norms and prerequisites. In addition, specific prerequisites have been included, for all investment projects.

\section{Research methodology}

To achieve the paper's objectives, the official papers and reports of the European Commission were researched. These documents provided insight into the strategic framework of all E.U. funds, including cohesion funds, and including the necessary prerequisites for fund allocation.

The European Commission issued rules, regulations, communications and reports regarding the cohesion policy and E.U. funding, in general, both for $2007-2014$, as well as for 2014 - 2020, for all member states. However, all these rules and regulations constitute a vast material.

Studying and analysing the financing for the two periods of time, as well as the estimates for the time frame between 2021 and 2027, several conclusions were drawn, regarding the evolution of the cohesion policy throughout time. These conclusions were also generated by analysing the achievements and the failings of the cohesion policy, as well as the causality of failings, by using the comparison method.

In addition, we analysed official documents published by the Ministry of European Funds, as well as documents published by other ministeries and Romania's Government. All these documents were available via their websites.

\section{Findings and Discussion}

The purpose is to analyse the achievements of the cohesion policy, at European level. To achieve this, at least two financial periods had to be analysed. The GDP per capita for the poorest regions within the E.U. has increased from $60.5 \%$ in 2007 to $62.7 \%$ in 2010 , and nowadays it is near the E.U. average.

Between 2007 and 2012, 594.000 new jobs were created across Europe. At the end of 2020, 1,1 million small and medium-sized enterprises (SMEs) will be supported to create 420.000 new jobs, aimed at helping 7,4 million unemployed people to search for a job and support 2,2 million people to engage in training courses. Through the support received at an European level, the cohesion policy was able to increase the employment rate of people aged 20 - 64 across the E.U. to $71 \%$; however, it did not achieve the goal of $75 \%$, as per the "Europe 2020" Strategy.

Through this cohesion policy, it is estimated that over 8 million children will benefit from new and modern schools; over 47 million people will have access to improved medical services. The policy shows results: for example, the unemployment rate across the E.U. has fallen from $10.9 \%$ in 2013 to $8.6 \%$ in 2016 and $7.7 \%$ in 2017 . Regional 
disparities in unemployment rates diminished as well. Up until 2017, people below the age of 25 continue to face difficulties when trying to get a job. Furthermore, the E.U. invested over 16 billion Euro within the digital economy for the development of electronic governing, IT\&C apps and SME development. Investments have also been made in high-speed networks, smart grids and intelligent energy distribution systems. These investments will provide broadband access to 14.5 million households; furthermore, direct investment aid was provided to 195.000 small and medium-sized enterprises, which are expected to create over 262.000 new jobs by the end of 2020 .

Concerning territorial cooperation, the E.U. advertised the participation of over 240.000 people in various transport mobility initiatives. Furthermore, over 6.900 SMEs will participate in research within cross-border projects, by the end of 2020 . Thanks to all these achievements and projects to be accomplished, the overall economy is expected to recover and gradually eliminate the fluctuations which persist both between member states, as well as among various regions. The question is whether or not these fluctuations will remain the same, without the support of the Cohesion Fund.

During 2021 - 2027, the E.U. has allocated over 373 billion Euro for its cohesion and regional development policies, focusing on closing gaps between states and regions. The proposed budget amounted to 1.279 billion Euro, taking inflation into account. Romania will receive 30.7 billion Euro, during 2021 - 2027, meaning more than 7 billion Euro more than during 2014 - 2020, being ranked fourth within the hierarchy of E.U. member states. The European Commission aims to modernise the cohesion policy, transforming it more into an investment policy as a tangible expression of European solidarity.

The E.U. provided five investment priorities for the new financial framework. Investments in regional developments will focus on the first two topics. Between $65 \%$ $85 \%$ of available resources from the Cohesion Fund and the European Fund for Regional Development will be allocated towards this area. In brief, the goal is a more intelligent Europe, driven by innovation, digitization and economic transformation; ultimately, this transformation will also drive European SMEs towards a Europe without carbon emissions, by enforcing the Paris Agreement, investing in energy trading, energy from renewable sources and combating climate change. Additionally, Europe must become even more connected through strategic, digital transport networks. Moreover, the goal is to achieve a more social Europe, with the goal of protecting social rights and supporting the quality of jobs, education, competencies, social inclusion and equal access to the health system.

In the economic field, cohesion policy set a priority objective, namely the modernization of the industry, especially in defamation regions, promoting a low-carbon, circular economy. The latter can create new jobs and support innovation.

Both the Cohesion Fund and the Regional Development Fund support innovation and the growth of digital technology in SMEs, as well as the adoption of digital technology and industrial modernization, in addition to supporting the fight against climate change. Economic analyses have revealed that industries in Southern and Eastern Europe require substantial support to reduce gaps as opposed to their counterparts within developed regions, since rural areas have a larger share in the economy and industrial transition is rather difficult within a globalized economy. 
Furthermore, local and regional authorities have to be more involved in managing European funds in the future. Local level investments must materialize in roads, public utilities, schools, hospitals and the extension of gas networks.

Another aspect of economic development includes the often-appalling quality of local administrations. This low quality reduces the overall impact of public investments, including the ones which are co-financed by the cohesion policy. The improvement of the efficiency of public administration would significantly amplify the impact of cohesion policies. At European level, productivity actually stagnated or increased by thin margins in recent years. As such, structural reforms are paramount, with the goal of improving competition, business environment stability, education, labour markets and social protection systems.

Within the transborder and interregional area, ultra peripheral regions benefit from special support from the Cohesion Fund. At this level, it is imperative that natural resources are jointly managed and environment protection is ensured.

At the moment, there is a "regional transborder mechanism", which proposes interregional and transborder cooperation programs for joint services and investments.

Through joint interregional and transborder cooperation, a new possibility to fund projects has been created: it involved the possibility of one region funding projects in other, remote regions across Europe.

The European Commission initiated the "creation of interregional innovation investments", through which "intelligent specialization" will be supported, in areas such as circular economy, cybernetic security and advanced manufacturing systems.

The asylum and migration fund will focus on the needs of migrants who arrive at the border, on a short term basis, and the Cohesion Fund will fund social and professional integration of migrants.

The new Cohesion Policy corresponds to the 2021 - 2027 period and must remain a financial investment instrument in three major areas: economic, social and territorial investments. However, the common budget for this time frame is $7 \%$ lower than the current E.U. budget. Still, although the budget is lower, the funds will be allocated more efficiently, as the overall policy will be modernized. For example, new elements will be added. The policy will direct and invest funds in all regions, will focus on regional development, will be accessible to European citizens and will have a stronger link with the European semester, so as to improve the investment environment. The newly added elements will aim to eliminate gaps between member states and regions within those member states.

According to the most recent statistics, $80 \%$ of E.U. citizens will live in urban areas, for which 1.6 billion Euro will be allocated, from the Cohesion Fund.

New criteria were introduced within the new cohesion policy framework, particularly on a social level, with the purpose of combating youth unemployment, boosting the educational level, combating climate change, receiving and integrating migrants. Also, bureaucracy was reduced by simplifying control methods, so as to benefit E.U. citizens.

Moreover, a new, unitary regulation framework was established, one which includes shared management. The European Commission will oversee the introduction of a unique portal, containing all the available financing for SMEs and a unique database for all E.U. managed projects. 
During 2007 - 2014, Romania had 19.7 billion Euro available, divided on 7 main Sectorial Operational Programs. By the end of 2014, it was decided the absorption rate was unexpectedly low and several programs were suspended due to irregularities such as attributing contracts through public auction procedures.

Of the sums which the E.U. allocated, only 6.1 billion Euro became part of the real economy, to support its competitiveness. Part of these funds were used for subsidies, preparing the labour force and infrastructure projects which unfortunately did not contribute to the sustainable development of the economy. Also during this time, several suspicions of fraud were raised, however, these only accounted for $1.2 \%$ of the total available funds.

The Cohesion Policy financed 138 large projects, between 2007 and 2014, the majority of which were in infrastructure - water distribution and sewage, road infrastructure, railroad infrastructure and waste management. As results, during 2007 and 2014, 51,203 jobs were created, over 411.000 workers were qualified, on a yearly basis, through the ESF, 558 research projects were supported and $385 \mathrm{~km}$ of modern roads and highways were built, through structural and cohesion funds.

The analysis showcased other potential causes for which the country was not able to take full advantage of all available funds; incompetence in managing money, oversight when it comes to eligibility criteria, also, the submitted projects did not create the jobs they were supposed to.

Due to these irregularities, the low rate was also maintained for the current period, namely 2014 - 2020. For this time frame, 23 billion Euro from the Cohesion Fund were allocated to Romania; of this amount, 15.06 billion Euro were allocated for less developed areas, 441.3 million Euro were allocated for developed areas, 453 million Euro were allocated for European territorial cooperation and 106 million Euro were allocated for youth employment.

Due to the complexity of the cohesion policy, it is not financed only from the Cohesion Fund, but also from other funds, which together, form the European Social Fund. In this case, 6.93 billion Euro come from the Cohesion fund, 4.8 billion Euro from the European Social Fund and the rest from the other 3 funds.

To achieve better results, the European Commission established 5 challenges for Romania, through the Partnership Accord, and under the incidence of the cohesion policy.

The first challenge regards people and society, as a whole. It aims to bring the overall occupation rate of the labour force to surpass $70 \%$ and aims to provide social inclusion to 580.000 citizens. For educational policies, the key performance indicators are a school dropout rate of $11.3 \%$ and a level of tertiary education of $26.7 \%$.

The level of occupation for the labour force in Romania for individuals aged 20 to 64 was of $63.9 \%$ in 2013 , as opposed to the European average of $68.4 \%$. In 2019 , this level reached $69.2 \%$, and came close to the targeted KPIs.

The unemployment rate in 2013 was of $35.4 \%, 7.5 \%$ higher than today's E.U. average rate, of $4.1 \%$. In 2013, 9.9 million individuals were part of the active population. The number of active employees grew from 6.2 million in 2013 to 6.5 million in 2019.

Concerning social inclusion, the decrease was supposed to be from 4.99 million in 2008 to 4.41 million in 2020; however, in 2017, the number of individuals was lower with 1.42 million individuals, decreasing by $8.5 \%$ as compared to 2008 . 
The school dropout rate decreased from $17.4 \%$ in 2012 to $16.8 \%$ in 2018 . The level of tertiary education was of $23.2 \%$ in 2013 , and of $26.3 \%$ in 2017 .

A large part of the undertaken obligations were achieved, with the exception of reducing the school dropout rate through political measures.

The second considerable challenge refers to transportation infrastructure and involves the improvement and accessibility of all regions and connecting them with international markets, by boosting a sustainable transportation mix, increased traffic safety, a decrease in travel times and the increased durability of urban transportation.

In 2014, Romania had $649 \mathrm{~km}$ of highways, out of a total of $16.886 \mathrm{~km}$ of roads, some of which had maintenance issues, but $50 \%$ of which were in good shape. By the end of 2018 , we had $803 \mathrm{~km}$ of highways, there are various other highways in various stages of being built, tallying up $138 \mathrm{~km}$, and others as projects, such as the one linking Transylvania to Moldova.

In terms of railroad transportation, train speed decreased from 50 - $60 \mathrm{~km}$ per hour to 30 - $40 \mathrm{~km}$ per hour, due to a lack of modernization. Lack of infrastructure investments causes serious issues. The speed of trains decreases. As it decreases, more locomotives and train wagons are required. Low speed means a lack of attractiveness on the part of the railroad system, which leads to the impossibility of recovering any investment made in locomotives and wagons. At the same time, only $37 \%$ of the railway network is electrified.

At the moment, modernization works are taking place across the 4th Corridor, also known as the PanEuropean Corridor. However, these works have been dragging on for 18 years. It is still not ready and some segments are not yet contracted. This Corridor means $800 \mathrm{~km}$ out of a total of $11.000 \mathrm{~km}$, which the railroad network has in Romania. Other important networks, such as the TEN-T Comprehensive or the Rhine - Danube network, are currently just projects.

There is actually a law concerning the Transylvania highway, which virtually links Transylvania to Moldova. Over 37 million lei were granted, as budgetary credits and over 9 million lei as commitment credits, for feasibility studies, for the section between Târgu Mureş and Târgu Neamţ. This is a section which will be financed through E.U. funding. These are highways started in 2014 , which have a low stage of completion, at the moment, of just $20 \%$.

A long term, coherent government policy is required, one which is connected to European requirements when it comes to transportation, particularly when it comes to railroads. Accomplishments in this sector are minimal, particularly due to the incompetence of those in charge of their administration.

Economic competitiveness is the third challenge. It involves the establishment of a compact, yet modern research environment, which places emphasis on the development needs of enterprises, mostly SMEs, and competitive sectors of the Romania economy, as well as the transformation of traditional sectors, through innovation and commercial expansion, seeking to boost the GDP quota allocated to research and development to $1.5 \%$, by 2020 .

"Romania has a National Competitiveness Strategy, for 2015 - 2020, which must be implemented, as it establishes measures for the underdeveloped sectors of the economy and which allows the national economy to connect to international economies", 
as per the 2019 INACO - REI Competitiveness Report in Romania. The country's innovation capacity is of just $31.1 \%$ of the E.U. average, according to the European Innovation Scoreboard of 2018. Furthermore, Romania is among the 20 E.U. economies which are still between the transition period and the third stage of economic development, namely from an economy based on efficiency towards an economy based on innovation. The country is situated last in the E.U. when it comes to the percentage of employees who work in science and technology (S\&T), with $27 \%$, meaning 1 in 4, as opposed to the E.U. average of $46 \%$, according to Eurostat. And while at European level, the average budget allocation for research \& development activities is of $2 \%$ of GDP, in Romania, this rate is of just $0.5 \%$ of GDP, of which $0.16 \%$ are government expenses, $0.05 \%$ are tertiary education expenses and $0.29 \%$ come from private funding, according to Eurostat. Further still, the percentage of GDP allocated to such activities was of just $0.48 \%$ in 2018 . Romania failed to reach this objective due to financing issues and failing to transpose the strategy's objectives into practice.

The fourth challenge refers to resources and involves moving towards a low emissions economy and low carbon initiatives, thus boosting the overall economy's energy efficiency, particularly when it comes to the construction sector, efficient resource allocation and environment protection. The national target set forth by the E.U. by 2020 is the reduction of greenhouse gas emissions by $19 \%$ and the increase of renewable energy to $24 \%$. The White Charta of 2011 set forth, as an objective, to reduce greenhouse gas emissions by 2050 with at least $60 \%$ as compared to 1990 levels. Moreover, an intermediary level of a $20 \%$ reduction by 2030 , as compared to 2008 levels, is targeted. In 2016, transportation accounted for roughly a quarter of total greenhouse gas emissions in the E.U., as opposed to $15 \%$ in 1990, making it the second highest emissions sector, right behind energy production. Numerous efforts to reduce emissions, both at an E.U. level, as well as for each member state, were focused on road transportation, as this sector accounts for $72 \%$ of all emissions within transportation.

Concerning energy efficiency, Romania still showcases aspects which have to be combated when it comes to the entire energy value chain, meaning production, transportation, distribution and consumption. Energy intensity is one of the highest in Europe (378.8 kgpe / 1000 Euro in 2012, Eurostat). Although the situation substantially improved, energy intensity is still three times higher than the E.U. average (143,2 kgpe / 1000 Euro).

Increasing energy efficiency when it comes to large, industrial consumers, can lead to considerable decreases in energy consumption, with a positive impact on the environment and resource conservation. The E.U. 27/2012/CE Directive confirms this significant savings potential for primary energy. High efficiency cogeneration has a positive impact on greenhouse gas emissions and energy consumption.

According to the latest inventory for greenhouse gas emissions (GES), which Romania issued in 2014 , the emissions of the energy sector accounted for more than $70 \%$ of total emissions. In 2017, greenhouse gas emissions were $10 \%$ lower than the E.U. established targets.

Moreover, Romania made a strong commitment to ensure that by $2020,24 \%$ of the energy it consumes will come from renewable resources, up from $18 \%$, in 2005 . This 
quota was fortunately surpassed in 2016 , when Romania reached a percentage of $25 \%$, an objective which was also achieved through support granted through several government programs. The fifth challenge refers to administration and governing, by improving the quality of provided public services. According to the Worldwide Governance Indicators Report, issued by the World Bank (2010; 2011), Romania was situated last when it comes to government efficiency because public administration faces a severe lack of efficiency, due to its excessive politicization, a high degree of bureaucracy and rampant corruption. The situation did not evolve considerably in the years following this report. The issue of perception, when it comes to the quality of public services, their degree of independence from political pressures, is aggravated by the lack of real reforms within. So far, no political party had the gumption to reform the system. Investors are among those who are dissatisfied with the current status quo, as they waste precious time when dealing with poorly prepared clerks, who operate a system which is not yet fully digitized.

Increased transparency within the decision making process is required to boost the overall efficiency of territorial authorities.

\section{Conclusions}

Many times, cohesion and regional development policies are believed to be synonymous. In our opinion, they differ; still, in most cases, their objectives are indeed identical. The regional development policy supports the cohesion policy, although their funding comes from different sources. The cohesion policy is closely linked to sectorial policies regarding transportation, the environment and education. The complexity of the cohesion policy resides in its horizontal character as well as in the difficulties required to finance it from other funds as well, as opposed to the cohesion fund; this is why it was always subject to reform and aligned with the objectives of the Europe 2020 strategy.

By analysing the two timeframes, namely 2007 - 2014 and 2014 - 2020, one can conclude that although financing grew tremendously, shortcomings were also present; moreover, the allocated financing was insufficient.

At a national level, the cohesion policy did not yield the expected results for 2007 2014 , since the absorption level was quite low. This was particularly due to the novelty of the European financing mechanism, but also due to the lack of institutions to manage these funds efficiently, lack of clear procedures and qualified staff, a lack of quality projects, and last but not least, suspicions of fraud; all of these factors could potentially breed corruption.

Financing for the 2014 - 2020 cohesion policy increased, but the same issues remained. On one hand, the E.U. established an ex-ante verification mechanism, to ensure funds are directed where they are needed; on the other hand, Romania did not boost the efficiency of the administration apparatus involved in managing E.U. funds. For 2014 2020, Romania sought to overcome the 5 aforementioned challenges, and results were seldom satisfactory, due to various factors, for instance the involvement of politics in the overall decision making process; one such example consists of allocating financial resources towards new projects while disregarding projects currently being implemented. 
An additional factor consists of the lack of an adequate legislative framework and long term, national development objectives, which in turn could receive multiannual funding, as European projects, such as highways or hospitals: these projects cannot be built during a year or two; they require multiannual financing, something which does not occur of in Romania.

Another factor which negatively influences the absorption rate consists of inefficient local and central public administration, underpaid, underqualified, overstaffed with politicians who often block projects, as per the interest of their parties and not the interest of the general public. The informatization process of the administration is not sufficient, if there is no online connection to other institutions, so as to save time when seeking approvals or notices.

The absorption rate in Romania, for 2019 , was of just $26 \%$, below the European average of $27 \%$.

An increase of cohesion policy funds is projected for $2021-2027$, and these funds must be directed towards solving the highway challenge, and improve the utilities infrastructure for various towns and villages and an overall simplification of the entire process of obtaining funds.

\section{References}

Dinu M., Socol C., Marinaș M., (2004) European Economy. A synopsis, Economic Publishing House, Bucharest

Dobrescu, E.M. ( 2008) Structural funds, Publisher Eurolobby, Bucharest

Lucian, P. (2016) The Economy of the European Union, "Lucian Blaga" University Publishing House, Sibiu

Miron, D. (2004) European Economy, Publisher Luceafărul, Bucharest

Popescu, Gh.(2007), European Economy, Economic Publishing House, Bucharest

Prisecaru, P. ( 2004) Common EU Policies, Economic Publishing House, Bucharest

Seventh report on economic, social and territorial cohesion My Region, My Europe, Our Future,

Available

at:

https://ec.europa.eu/regional_policy/sources/docoffic/official/reports/cohesion7/7cr.pdf

European Commission, 2014, Introduction to EU cohesion policy 2014-2020. Available at: https://ec.europa.eu/regional_policy/sources/docgener/informat/basic/basic_2014_ro.pdf

Consolidated Version of the Treaty on the Functioning of the European Union, Available at: https://eur-lex.europa.eu/legal-content/EN/TXT/PDF/?uri=CELEX:12012E/TXT\&from=EN

https://ec.europa.eu/regional_policy/sources/docgener/informat/basic/basic_2014_en.pdf

https://cohesiondata.ec.europa.eu/2014-2020/Total-allocations-of-Cohesion-Policy-2014-2020-

Bre/nvqb-bd9b

http://www.europarl.europa.eu/EPRS/Funding_Guide_EN.pdf

https://ec.europa.eu/regional_policy/en/policy/evaluations/ec/2007-2013/

https://ec.europa.eu/esf/http://www.cercetare.rei.ase.ro/track-4-evaluation-of-competitiveness 